\title{
METHODICAL ASPECTS OF VALUATION THE COST OF GOODS AND SERVICES AS INTELLECTUAL CAPITAL INNOVATION ECONOMY
}

\author{
E. Bezpalko, T. Belova \\ National University of Food Technologies
}

\begin{tabular}{l} 
Key words: \\
Sign for goods and \\
services \\
Ttrademark \\
Brand \\
Approaches and methods \\
of mark evaluation for \\
goods and services \\
\hline \multicolumn{1}{c}{ Article history: } \\
Received 11.01.2018 \\
Received in revised form \\
18.01.2018 \\
Accepted 09.02.2018 \\
\hline Corresponding author: \\
E. Bezpalko \\
E-mail: \\
bezpalko.elen@gmail.com
\end{tabular}

ABSTRACT

The article is devoted to the study of the economic essence of estimating the value of a sign for goods and services as one of the important procedures of an innovative economy. The concept of a trademark as a powerful factor of competitiveness of the enterprise is highlighted. The functional purpose and real possibilities of its use are defined: advertising of goods, guaranteeing the quality of goods and protection against unfair competition or counterfeiting. The purpose of estimating the value of a trademark is considered, taking into account the financial and marketing concepts of evaluation. It is determined that they conduct such a procedure in the case of valuation of intangible assets of the enterprise as a whole, in order to dispose of the rights to a trademark and in cases of resolving conflicts that may be related to the illegal use of another's trademark. It is established that the financial concept is a quantitative objective assessment of the value of a trademark, and the marketing concept of evaluation is aimed at investigating the effectiveness of the marketing strategy and its tools for managing the trademark as a brand. A variety of approaches and methods for assessing the value of a trademark are summarized and analyzed. It is revealed that the presented methods are based on the use of information about additional incomes of the enterprise related to the use of the trademark; about the costs of its development and promotion of the product under this trademark; on the conditions of similar transactions taking place on the market.

The common and distinctive features of different methods of estimating the value of a trademark are identified, boundaries are defined and recommendations on the appropriateness of their application depending on specific situations are given.

In the framework of the income approach, the methods of estimating trademarks are systematized and presented: the method of profit, the method of exemption from royalties, the economic method, the method based on the discounting of future cash flows. It is proved that the real value of the trademark will enable the owner to monitor the change in the level of consumer loyalty to him, to carry out an analysis of his expenses, and the size of the price surcharge will serve as an indicator of the efficiency of the functioning of the trademark in the market.

DOI: $10.24263 / 2225-2924-2018-24-1-9$ 


\title{
МЕТОДИЧНІ АСПЕКТИ ОЦІНКИ ВАРТОСТІ ЗНАКА ДЛЯ ТОВАРІВ І ПОСЛУГ ЯК ІНТЕЛЕКТУАЛЬНОГО КАПІТАЛУ ІННОВАЦІЙНОÏ ЕКОНОМІКИ
}

\author{
О.В. Безпалько, Т.Г. Бєлова \\ Національний університет харчових технологій
}

Стаття присвячена дослідженню економічної сутності оичіки вартості знака для товарів і послуг як однієї з важливих процедур інноваційної економіки. Висвітлено уявлення про товарний знак як потужний чинник конкурентоспроможності підприємства. Визначено функиіональне призначення та реальні можливості його використання: рекламування товару, гарантування якості товару та захист від недобросовісної конкуренції або підробок. Розглянуто цілі очінки вартості товарного знака з урахуванням фінансової $i$ маркетингової концепцій очінки. 3'ясовано, щуо проводять таку процедуру у разі оцінки нематеріальних активів підприємства в цүілому з метою розпорядження правами на товарний знак та у випадках урегулювання конфліктних ситуащіï, які можуть бути пов'язанні з незаконним використання чужого товарного знака. Встановлено, щуо фінансова концееція є кількісною об 'єктивною оцінкою вартості товарного знака, а маркетингова концепція оцінки спрямована на дослідження ефективності маркетингової стратегіi та ї̈ інструментів щзодо управління товарним знаком як брендом.

Узагальнено $i$ проаналізовано різні підходи та методи оиінки вартості товарного знака. З'ясовано, щзо представлені методи базуються на використанні інформації про додаткові доходи підприємства, щзо пов'язані з використанням товарного знака, про затрати на його розробку і просування товару під ичим товарними знаком, про умови аналогічних угод, щзо відбуваються на ринку. Виокремлено спільні та відмінні характерні ознаки між різними методами оцінки вартості товарного знака, визначено межі $і$ надано рекомендації щуодо доречності їх застосування залежно від конкретних ситуачій.

У рамках дохідного підходу систематизовано $i$ представлено методи оцінки товарних знаків: метод преміального прибутку, метод звільнення від роялті, економічний метод, метод на основі дисконтування майбутніх грошових потоків. Доведено, щчо реальна вартість товарного знака дасть змогу підприємству-власнику стежити за зміною рівня лояльності споживачів до нього, проводити аналіз здійснюваних у нього витрат, а сам розмір ияінової надбавки слугуватиме індикатором ефективності функціонування торговельної марки на ринку.

Ключові слова: знак для товарів і послуг, товарний знак, бренд, підходи та методи очінки знака для товарів і послуг.

Постановка проблеми. Основною ознакою інноваційного розвитку економіки є те, що більша частина прибутку створюється не стільки матеріальним виробництвом і концентрацією фінансів, скільки інтелектом людей, справжніх висококваліфікованих фахівців своєї справи. В розвинутий економіці потенціал підприємств може на $30-60 \%$ складатися з нематеріальних активів. 
При цьому на питому вагу знаків для товарів і послуг у нематеріальних активах може припадати до $80 \%$ [2]. Саме тому в умовах сьогодення оцінка цього виду інтелектуального капіталу досить важлива й актуальна для його власника.

Аналіз останніх досліджень і публікацій. Істотний внесок у розвиток теорії брендінгу та оцінки вартості знаків для товарів і послуг зробили відомі зарубіжні та вітчизняні вчені, зокрема: Д. Аакер [1], К.Л. Келлер Л. [3], Г.В. Сміт [5], Л. Чернатоні, М. МакДональд [8], О. М. Азарян [7], А. А. Бовін [2], Т.В. П'ятак [4], С.А. Старов [6], Н. Чухрай, Р. Патора [9], О.М. Ястремська та багато інших. Також свої практичні методики багатокритеріальної оцінки вартості марочного капіталу пропонують такі компанії, як: Young \& Rubicam, V-Ratio, Interbrand, Brand Finance тощо. При цьому ряд питань щодо виокремлення відмінностей між підходами, концепціями, методами оцінки товарних знаків і доречність їх використання залежно від цілей оцінки потребує додаткового наукового опрацювання й уточнення методичних особливостей.

Метою статті $є$ дослідження особливостей різних підходів і методів оцінки вартості знака для товарів та послуг, встановлення взаємозв'язку і розмежування відмінних ознак між ними з виокремленням їх істотних переваг, недоліків і можливих меж застосування.

Викладення основних результатів дослідження. Перед тим, як розглянути теоретичні та методичні особливості оцінки вартості знака для товарів і послуг доцільно, на наш погляд, зупинитися на функціональному призначенні товарних знаків і можливостях їх використання.

Знак для товарів і послуг - це позначення, за яким товари й послуги одних осіб відрізняються від товарів і послуг інших осіб. Саме таке визначення товарного знака закріплено статтею 1 Закону України «Про охорону прав на знаки для товарів та послуг». Зважаючи на це тлумачення, головним завданням товарного знака $є$ ідентифікація товару та його виробника на ринку. При цьому він виконує одночасно ряд функцій:

- рекламування товару, що допомагає його просуванню та максимізації доходу, оскільки репутація і впізнаваність товарного знака допомагають завоювати довіру споживача;

- гарантування якості товару та захист від недобросовісної конкуренції й підробок.

Володіння загальновідомим товарним знаком рівнозначне володінню значним фінансовим капіталом. Широко відомий товарний знак - це потужний чинник конкурентоспроможності підприємства, хоча його підтримка і вимагає постійних вартісних та інтелектуальних інвестицій. Але окупність таких вкладень досить швидка тому, що можна розраховувати на збільшення продаж, що викликане реакцією покупців на знайомий товарний знак і можливістю підвищення рівня цін на продукцію відомої марки. Тож цінність відомого товарного знака для правовласника полягає в тому, що він створює додаткові грошові потоки порівняно 3 товаром, який немає таких привілей. Зміни у вартості товарного знака $\epsilon$ своєрідною оцінкою ефективності маркетингової політики підприємства, тому будь-якому власникові такого капіталу необхідно мати набір інструментів для оцінки і максимізації його вартості. 
Оцінка - це процес визначення вартості, ретельний аналіз, який включає інформацію про сам об'єкт оцінки, про ринок як у цілому, так і в розрізі певного сегмента, виконання розрахунків, заснованих на одночасному обліку багатьох кількісних і якісних факторів. Розрахунок вартості товарного знака це процес обчислення грошового еквівалента прав на нього. Проводять таку процедуру, як правило, тоді, коли необхідно:

- оцінити нематеріальні активи підприємства в цілому з метою збільшення його вартості, наприклад, для купівлі або продажу бізнесу, при злиттях підприємств або при переговорах з інвестором тощо;

- розпоряджатися певним чином правами на товарний знак, наприклад, при внесенні його вартості в уставний капітал підприємства, при франчайзингу або при відчуженні права, при використанні товарного знака як застави в банках тощо;

- врегулювати конфліктні ситуації, які, наприклад, можуть бути пов'язані 3 незаконним використання чужого товарного знак, з метою обгрунтування суми компенсації як упущеної вигоди правовласника тощо.

При оцінці товарного знака варто зважати на фінансову і маркетингову складову оцінки, які мають свої особливості. Фінансова концепція є кількісною об'єктивною оцінкою вартості товарного знака, що дає змогу обчислити, яку різницю дає до додаткової вартості наявність товарного знака порівнянно 3 умовним середнім продуктом. Така оцінка використовується, як правило, для переговорів 3 інвесторами, 3 метою визначення розміру роялті і франчайзингових платежів, для з'ясування величини внеску в статутний фонд підприємства тощо. Маркетингова концепція оцінки, як правило, спрямована на дослідження ефективності маркетингової стратегії та іï інструментів щодо управління товарним знаком як брендом. Вона використовує різні підходи , але в основному базується на багатокритеріальних методах оцінки вартості товарного знака, основою яких є орієнтація на якісні показники. Ці методи дають змогу оцінити як поточні, так і потенційні можливості товарного знака в отриманні прибутку, але при цьому вони, як правило, опираються на дані маркетингових досліджень та різні опитування споживачів, а тому досить суб'єктивні, бо достовірність їх результатів багато в чому залежить від точності цих даних.

Як свідчать численні наукові теоретичні напрацювання в цій галузі, методи оцінки товарного знака, як правило, базуються на використанні інформації:

- про додаткові доходи підприємства, що пов'язані з використанням товарного знака;

- про затрати на його розробку і просування товару під цим товарним знаком;

- про умови аналогічних угод, що відбуваються на ринку.

Для визначення цінності товарного знака використовуються насамперед стандарти оцінки, прийняті Міжнародною радою зі стандартів, найважливішим з яких прийнятий у 2010 р. зусиллями фахівців з 14 країн. Це міжнародний стандарт ISO 10668 «Brand valuation. Requirements for monetary brand valuation»(«Оцінка бренду»), який регламентує основні підходи і методи оцінки вартості бренду як самостійного нематеріального активу. Згідно з цим стандартом, бренд — це маркетинговий нематеріальний актив, необмежений назвою, терміном, знаком, символом, логотипом, дизайном або їх комбіна- 
цією, призначений для ідентифікації товарів і/або послуг, що створює образи й асоціації у свідомості учасників бізнес-процесу і таким чином забезпечує економічні вигоди/вартість. Здійснюючи оцінку вартості активу за цим стандартом, оцінювач повинен провести три види аналізу (юридичний, поведінковий і фінансовий), перш ніж він винесе остаточне рішення про його вартість. Крім того, необхідно враховувати, що значимість, а отже, й вартісна оцінка знака для товарів і послуг у набагато більшому ступені, чим інших нематеріальних активів (винаходів, промислових зразків тощо) залежить від репутації підприємства, що володіє ним, тривалості його перебування на ринку і якості товару чи послуги.

Міжнародний стандарт ISO 10668 традиційно виділяє три альтернативних підходи до оцінки товарного знака: дохідний, витратний і ринковий. У витратному підході, згідно з назвою, визначаються і розраховуються витрати, які поніс власник у зв'язку із створенням, правовим захистом та розвитком товарного знака, тобто оцінюється вартість доведення звичайного товару до того ж положення на ринку, що й оцінюваний товар під певною торговельною маркою. Такий підхід заснований на припущенні, що інвестор не заплатить за актив більше, ніж вартість відновлення, заміни або відтворення активу аналогічної корисності.

Оцінка товарного знака витратним підходом передбачає такий розрахунок:

$$
P V=1,4 \cdot V \cdot k_{1} \cdot k_{2} \cdot\left(1+d_{1} \cdot d_{2}\right),
$$

де $V$ - собівартість розробки знака для товарів до послуг, одержання правової охорони і маркетингових витрат на рекламу і просування, грн; $k_{1}-$ коефіцієнт, що враховує термін використання знака для товарів і послуг з моменту початку широкомасштабної рекламної кампанії по просуванню його на ринок (діапазон зміни коефіцієнта в межах від 1,0 до 2,0 залежно від кількості років використання знака для товарів і послуг (наприклад, 1 рік $-k_{1}=1,0 ; 2$ роки $-k_{1}=$ $=1,2 ; 10$ і більше років - $\left.k_{1}=2,0\right) ; k_{2}-$ коефіцієнт, що враховує тривалість функціонування підприємства на ринку (діапазон зміни коефіцієнта від 1,0 до 2,0 , розрахунок даного показника ідентичний розрахунку коефіцієнта $\left.k_{1}\right) ; d_{1}-$ частка підприємства на ринку; $d_{2}$ - частка продукції, що реалізується під цим товарним знаком у загальному обсязі продукції підприємства.

Величину отриману в результаті розрахунку $\left(1+d_{1} \cdot d_{2}\right)$ називають ще масштабністю використання знака для товарів і послуг залежно від величини товарообігу. Деякі науковці [9] числове значення цього показника переводять у відповідний коефіцієнт, межі коливання якого від 1,0 до 2,0 з кроком 0,2 залежно від величини товарообігу (наприклад, до 10 тис. американських доларів на місяць - 1,0; від 10 до $50-1,2$; від 50 до $100-1,4$; від 100 до $500-1,6$; від 500 до $1000-1,8$; більше 1 млн американських доларів на місяць - 2,0).

Перевагою такого підходу є те, що досить легко підрахувати всі витрати, пов'язані з цим процесом. А от недолік набагато суттєвіший: не можна 3 великою впевненістю сказати, що існує прямий зв'язок між інвестованими коштами і досягнутої цінністю. Як доводить практика, витрати не завжди збігаються з реальною оцінкою, можна витратити великі кошти на дослідження, розробку, рекламу і просування, а товарний знак так і не стане брендом 
підприємства. Тобто при використанні цього методу існує ризик завищити реальну вартість об'єкта оцінки. Крім того, витратний метод часто грунтується на даних минулих періодів і при цьому не враховується потенціал майбутнього прибутку підприємства. 3 огляду на вищевикладене, такий підхід можна використовувати, коли інші підходи оцінки неможливо застосувати i при цьому доступні надійні дані для розрахунку таких витрат. Крім того, витратний підхід доцільно використовувати в ситуаціях, коли товарний знак знаходиться лише на ранній стадії свого розвитку, або для молодих брендів.

Згідно з ISO 10668 ринковий підхід вимірює цінність знака для товарів і послуг, грунтуючись на тому, яку суму інші покупці заплатили за схожі активи. При використанні такого підходу обчислюється потенційна вартість можливого продажу знака для товарів і послуг на вільному ринку. Цей підхід має на увазі підбір ринкових аналогів оцінки вартості даного активу, тобто аналогів порівняних за силою та ринковими можливостями. А це, по суті, і є основним його недоліком, оскільки для об'єктивного визначення вартості необхідний активно функціонуючий ринок купівлі-продажу торговельних марок, щоб на ринку була певна кількість угод, які можна було б порівняти з тією, що потрібно оцінити, щоб встановити критерії. Але такі угоди відбуваються не так часто і не завжди інформація про них доступна. 3 огляду на це ринковий підхід, як і витратний, застосовується нечасто, тому що складно знайти аналоги, адже унікальність товарного знака захищена законом. Перевагою даного підходу можна вважати те, що у разі наявності достатньої інформації про товарианалоги, він досить простий і зручний у використанні. Крім того, даний підхід має безпосередній прямий зв'язок із ринковою ціною товарного знака. Це може сприяти навіть збільшенню його вартості, в чому дуже зацікавлений власник.

Дохідний метод - це метод, заснований на оцінці здатності товарного знака приносити дохід. Він дає відповідь на запитання, які вигоди зможе отримати майбутній покупець у разі використання об’єкта оцінки. Дохідний підхід є загальновизнаним і найбільш поширеним. Його основною перевагою $\epsilon$ те, що оцінюється саме майбутні перспективи, а не минулий і поточний стан справ, що характерно для витратного і ринкового методів. Такий підхід вимагає наявності чіткої і конкретної інформації про ринкові перспективи товару, для якого використовується оцінюваний об'єкт, але дані можуть бути досить суб'єктивними, що і є основним недоліком. Дохідний підхід доцільно використовувати для товарних знаків, які працюють на стабільних ринках або для розрахунку вартості бренду.

У рамках дохідного підходу існує багато різноманітних методів оцінки товарних знаків (метод преміального прибутку, метод звільнення від роялті, економічний метод, метод на основі дисконтування майбутніх грошових потоків тощо). Всі вони мають певні особливості, але їх об’єднує:

- визначення економічного ефекту від використання об' єкта оцінки;

- прогнозування майбутніх грошових потоків, з урахуванням тривалості часу корисного використання товарного знака;

- приведення майбутніх грошових потоків до теперішньої вартості.

У загальному вигляді оцінка товарного знака на основі дохідного підходу передбачає такий розрахунок: 


$$
P V=\sum_{t=1}^{n} P_{t} \cdot \frac{1}{\left(1+\frac{i_{t}}{100}\right) t}
$$

де $P_{t}$ - обсяг вигод, одержуваних за рахунок використання об'єкт оцінки в період $t$, грн; $i_{t}$ - ставка дисконту, $\% ; n$ - число періодів $t$, у яких передбачається одержання певних вигод.

В основі методу преміального прибутку (Premium profit) лежить постулат про те, що товар під розкрученою торговельною маркою можна реалізувати за більш високою ціною, ніж звичайний товар. Вартість товарного знака за такою методикою визначається на основі різниці в обсягах продажу таких товарів у грошовому еквіваленті, за умови, що обидва види товару реалізовувалися за однаковою ціною. Суттєвим недоліком даного методу є складність знаходження аналога для здійснення такого порівняння.

Метод звільнення від роялті (the relief from royalty method) $\epsilon$ досить поширеним при визначенні грошових потоків від використання торговельної марки. Відповідно до цього методу передбачається, що всі доходи підприємство отримує як економію сум, які необхідно було б заплатити, якби права на використання об'єкта оцінки належали іншому підприємству. Вартість товарного знак визначається як чиста приведена вартість усіх платежів роялті, отриманих його власником. Ставка роялті може бути визначена в результаті аналізу всіх доступних даних по ліцензійних платежах аналогічних товарних знаків. Основна складність - це визначення сум роялті. Фахівці вважають, що для такого немасового ринку, як ринок товарних знаків поняття «аналогічна угода» $є$ досить умовним, тому що кожна угода $є$ унікальною за своєю суттю.

Економічний метод базується на визначенні величини внеску торговельної марки в доходи підприємства, скорегованої на показник ринкової стійкості підприємства, який є співвідношенням ринкової ціни акцій до чистого прибутку підприємства на акцію. Цей метод доречно застосовувати за умов розвинутого фондового ринку. Однак складність полягає також і у виокремленні тієї частини доходу підприємства, яка забезпечується нематеріальними активами, зокрема торговельною маркою.

Метод на основі дисконтування майбутніх грошових потоків $є$ найближчим за своєю суттю до основного призначення товарного знака - генерування протягом певного періоду додаткового потоку грошей, які додаються до основного продукту. Цей період є часом корисного використання об'єкта оцінки, протягом якого він гарантовано буде приносити підприємству дохід.

Отже, існують різні підходи і методи оцінки вартості товарного знака, але жоден із них не позбавлений недоліків. Тому в кожній конкретній ситуації використання певного підходу та методики повинно бути аргументовано обгрунтовано. Крім того, є очевидним, що використання декількох підходів дає змогу зробити більш точну оцінку і більш переконливо обгрунтувати підсумкову вартість об'єкта оцінки.

Незважаючи на те, що дохідний підхід в оцінці товарних знаків є найпопулярнішим, вважаємо доречним використовувати комплексний підхід, 
який дає змогу узгодити результати отримані за допомогою різних підходів до оцінки. Тоді формула вартості знака для товарів і послуг матиме вигляд:

$$
P V=a_{1} \cdot P V_{1}+a_{2} \cdot P V_{2}+a_{3} \cdot P V_{3},
$$

де $P V_{1}$ - вартість товарного знака, розрахована за витратним підходом; $P V_{2}-$ вартість товарного знака, розрахована за ринковим підходом; $P V_{3}$ - вартість товарного знака, розрахована одним із методів дохідного підходу; $a_{1}, a_{2}, a_{3}$ коефіцієнти значимості оцінки вартості знака для товарів та послуг, відповідно, за витратним, ринковим і дохідним підходами, при умові, що $a_{1}+a_{2}+a_{3}=1$.

Дані коефіцієнти можуть бути визначені експертним шляхом з урахуванням конкретної ситуації, повноти і достовірності вихідної інформації та цілей оцінки вартості знака для товарів і послуг.

\section{Висновки}

Сучасні вимоги інноваційної економіки підкреслюють важливість оцінки вартості знака для товарів і послуг як інтелектуального капіталу. Існують різні підходи та методики його оцінки, характеризуються певним перевагами, але мають і ряд недоліків. Методи оцінки вартості постійно вдосконалюються i пристосовуються до мінливих умов сьогодення. Комплексний підхід до процесу оцінки 3 урахуванням значущості того чи іншого підходу залежно від цілей оцінки забезпечує найбільш об'єктивний і виважений результат. Реальна вартість товарного знака дасть змогу підприємству-власнику стежити за зміною рівня лояльності споживачів до нього, проводити аналіз здійснюваних у нього витрат, а сам розмір цінової надбавки може служити своєрідним індикатором ефективності функціонування торговельної марки на ринку.

\section{Література}

1. Аакер Д. Создание сильных брендов: [пер. с англ.] / Д. Аакер. - Москва : Издательский дом Гребенникова, 2003. - 439 с.

2. Бовин А.А. Управление инновациями в организациях / А.А. Бовин, Л.Е. Чередникова, В.А. Якимович. - Москва : Омега-Л, 2006. - 415 с.

3. Келлер К.Л. Стратегический бренд менеджмент: создание, оценка и управление марочным капиталом / К.Л. Келлер. - Москва : Вильямс, 2005. — 704 с.

4. П’ятак Т.В. Оцінка вартості товарного знака (бренду) компанії / Т.В. П'ятак, В.О. Ігумнова // Вісник НТУ «ХПІ». Серія: Актуальні проблеми управління та фінансово-господарської діяльності підприємства. — Харків : НТУ «ХПІ». — 2013. — № 24(997). — С. $114-121$.

5. Смит Г.В. Оценка товарных знаков: [пер. с англ.] / Гордон В. Смит. - Москва: ИД «Квинто-Консалтинг», 2010. - 384 с.

6. Старов C.A. Управление брендами: учебник / С.А. Старов; Высшая школа менеджмента СПбГУ. - Санкт-Петербург : Изд-во «Высшая школа менеджмента», 2008. - 500 с.

7. Стратегія ефективного брендингу / О.М. Азарян [та ін.]. Донецьк : Вебер (Донецька філія), 2009. - 280 с.

8. Чернатони Л. Брендинг. Как создать мощный бренд: учебник для ВУЗов / Л. Чернатони, М. МакДональд. - Москва : ЮНИТИ-ДАНА, 2006. — 559 с.

9. Чухрай $H$. Товарна інноваційна політика: управління інноваціями на підприємстві: підручник / Н. Чухрай, Р. Патора. - Київ : КОНДОР, 2006. - 398 с. 